Katarzyna Kołodziejczyk, $\mathrm{PhD}$ in Art

Adjunct at the Chair of History of Architecture, Urban Planning and Art

Institute of History of Architecture and Monument Conservation

Faculty of Architecture, Cracow University of Technology

\title{
ARTISTIC INSTALLATION IN HISTORIC SPACE AS A TOKEN OF CULTURAL IDENTITY
}

\section{Abstract}

Artistic installation understood as art in a public space today constitutes a visually attractive method of healing and new characterization of aesthetically degraded places and landscapes, deprived of their cultural sense. Such works, created in the existing public space, by adding other contexts and symbolic meanings construct a completely new quality of a place, generate emotional sensations and experiences referring to the context of a place, the history of one's ancestors and cultural heritage. An analysis of selected realisations clearly indicates that an artistic installation perceived as a visual activity in a public space, is methodologically and technically based on previous identification and interpretation of the spirit of the place (genius locci), and as such an activity it could become an instrument used for projecting a forgotten or hidden past, restituting one's own cultural heritage in the social memory. It can be confirmed by such creations recorded in the public space as the famous arrangement of preserved relics of the house of Benjamin Franklin in Philadelphia, designed by Venturi and Rauch, realised in 1976, whose non-existent above-ground form was outlined in the form of a steel openwork skeleton - a phantom of the building; or a series of phenomenal steel-wire sculptures by a young Italian artist, Eduardo Tresoldi, evoking virtually realistic forms of non-existing historic buildings in the public space. Another well-known example is the artistic installation on the Bohaterów Getta Square in Krakow in the form of 70 chairs sculpted in metal, symbolically commemorating victims of the Holocaust. Those results prove the significance of artistic installation as a specific spatial token which can also be a transmitter of concrete content associated with the site of its location. In modern public space there exist numerous historic sites which, as a consequence of various transformations, have been deprived of artefacts characteristic for them, and thus the current image makes the cultural identification of the site practically impossible. In a situation when relics of those artefacts preserved in various forms (most frequently archaeological stratigraphy), cannot be exhibited for technical or doctrinal reasons, an artistic installation can become an efficient tool - transmitter of the spirit of the place. 


\section{Introduction}

Artistic installation in a public space is an artistic activity that can be experienced by anyone of us, regardless of religious beliefs, social or intellectual conditions. Examined in the category of mass art that engages the viewer in the creative process, it acquires a performative character and generates an aesthetic experience ${ }^{1}[1]$. Also in this sense it can constitute a specific kind of artistic documentation (see chapter 2), serving as a memorial site. By means of contemporary visual methods of healing, it can become an attractive place for educational exhibitions or presentations. Observing such activity in the contemporary world, one can distinguish a group of artistic installations that fit in with the tendency to revitalise both the forgotten and the newly re-discovered areas, which bear traces of past history. Applying that kind of artistic activity to the field of conservation design, we touch upon the problem of a cultural identity of a place, our individual and collective affiliation. In this context, an artistic installation can turn out to be an extremely significant interference into public space, serving as an identity token, a symbol, a code or a trace of memory. And treated in this way, it perfectly fits the role of an information source, a transmitter, becoming a reliable source of history, a means for conveying vital messages, images or sounds. It is a more and more frequent phenomenon in the public space, although so far it has not been classified as a concrete art discipline, fitting somewhere in between: visual arts, architecture and art conservation. Through this kind of interference in the public space we can also promote education, science, knowledge concerning both the history of art and other disciplines either inextricably related to it, or mutually complementary. We address here a very sensitive issue of cultural identity, the affiliation to a given social group. Naturally, the issue of cultural identity is connected to the issue of ethnic identity and the notion of the spirit of the nation. It is a problem discussed at length on the level of ethnography, sociology or cultural anthropology, nut also in archaeology, socio-economic sciences or even psychology, as personality integration and the need for affiliation. ${ }^{2}[2]$

\footnotetext{
1 The author uses the term aesthetic experience as understood in accordance with the definition by Roman Ingarden; [att.: R. Ingarden, Studia z estetyki, vol. III, Warszawa 1970].

${ }^{2}$ Z. Benedyktowicz, D. Markowska, O niektórych problemach identyfikacji kulturowej w procesie porozumiewania się, Etnografia Polska 1988, vol. XXIII, z. 2, ISSN 0071-1861, p. 205-207.
} 


\section{Artistic installation as a form of artistic documentation: healing, revitalisation, exhibition, education}

Artistic documentation is a term introduced by the author for the need of her research concerning artistic installations in public space in the context of healing, revitalisation, exhibition and education, and consequently determining cultural identity. It is a select notion and attributed by the author to concrete activities in public space, oscillating between visual arts, architecture and artwork conservation. According to the author, the notion fits into a broad spectrum of the problem concerning the function of documentation in modern art, understood [after: Łukasz Guzek] $]^{3}[3]$ as a shift towards its independence. It is intended to provoke a change in the way of thinking concerning various forms of documentation and opportunities for its use, treating documentation as art in its own right, a new, separate discipline among the scientific and artistic circles.

Artistic installation can fulfil the function of a document if it meets concrete requirements. The first of those is the context of a place, i.e. considering the historical and social context of a place. It means that the creative act must be preceded by a detailed analysis of the cultural matrix of the place, a research which takes into account its historic, architectonic, geographical, topographic, environmental, and social aspects. In other words, we must learn the history of the place and feel its spirit (genius locci). And only then are we ready to fulfil the next condition that is discovering hidden meanings in space, their processing and presentation depending on the time and place, since art is a cultural fact. An installation in itself is a communications phenomenon raised to the rank of art. Because of its inter-media character, it touches directly upon the very process of mediation which is deeply contextual. Imparting the form of a document to an installation we open new possibilities for categorising art. The form we create is to serve conveying information. Therefore, we are dealing with receiving information through art instead of information about art, which similarly fulfils the documenting function.

The other refers to conceptual activities. As Grzegorz Dziamski attempts to prove in his monograph ${ }^{4}$ [4], documentation has taken a vital place in contemporary art: Conceptual art did not so much replaced artwork with documentation, or turned documentation into a substitute of artwork, as introduced the distinction between artwork and art documentation. ${ }^{5}$ [5] It should not be confused with the notion of artistic documentation, though it would be safer to use the

\footnotetext{
${ }^{3}$ Ł. Guzek, Funkcja dokumentacji w sztuce współczesnej, [in:] Sztuka i dokumentacja, no 3/2010, p. 5-13.

${ }^{4}$ G. Dziamski, Przełom konceptualny i jego wpływ na praktykę i teorię sztuki. Filozofia i Logika (Poznań: Wydawnictwo Naukowe UAM, 2010), p. 250-51.

${ }^{5}$ G. Dziamski, Przełom konceptualny..., op.cit., p. 252.
} 
term documentation through art to distinguish it from documentation of art. Dziamski points out the intellectual context of art and documentation, emphasising information about art and not art itself as its main factor ${ }^{6}[6]$. Some of Dziamski's assumptions we can translate into our needs, after changing the main assumption to information through art.

The category of experience seems to serve the function of artistic documentation that is a key function for installations. In this case it is the viewer's experience which becomes the reconstruction of the aesthetic system. It is a real experience serving a creative role complete with its content and form, which as a final effect obtains a concrete form located in time and acquiring an aesthetic dimension. In this way, experiencing art becomes a real i.e. a life experience $^{7}[7]$.

\section{Artistic documentation or information through art}

Artistic installation, understood as art in public space, today constitutes an attractive, visual method of healing and a new characterisation of aesthetically degraded places and cultural landscapes and deprived of their cultural sense. Such works of art created in the existing public space, by adding other contexts and symbolic meanings construct an entirely new quality of the place, generate emotional sensations of an experience related to the context of the place, ancestors' past and cultural heritage. An analysis of selected realisations clearly indicates that an artistic installation examined as a visual activity in the public space, is methodologically and technically based on previously recognising and interpreting the spirit of the place (genius locci), and as such it can become an instrument used for projecting a forgotten or hidden past, and restituting one's own cultural heritage in the social memory. The testimony to it are such creation recorded in the public space as the famous, realised in 1976, arrangement of preserving relics of the house of Benjamin Franklin in Philadelphia designed by Venturi and Rauch, whose non-existent above-ground form was outlined in the shape of a steel openwork skeleton - a phantom of the building, or a series of phenomenal steel-wire sculptures by a young Italian artist, Eduardo Tresoldi, evoking virtually realistic forms of non-existent historic buildings in the public space. Another well-known example is the installation on the Bohaterów Getta Square in Krakow in the form of 70 chairs sculpted in metal, symbolically commemorating the victims of the Holocaust. Those results prove the significance of artistic installation as a specific

\footnotetext{
${ }^{6}$ P. Sztabińska, Dokumentacja, ślad i kreacja artystyczna, [in:] Sztuka i Dokumentacja no 10 (2014), p.75-82.

${ }^{7}$ Ł. Guzek, Biografia w badaniach nad sztuk performance. Proponowane zakresy tematyczne i metody, [in:] Sztuka i Dokumentacja, no 11 (2014,) p. 104-105.
} 
spatial token that could also be a transmitter of concrete content associated with the site of its location. In the contemporary public space there are many historical sites which, as a result of diverse transformations, have been deprived of artefacts characteristic for them, and therefore their current image makes the cultural identification of the place virtually impossible. In a situation when relics of those artefacts preserved in various forms (most frequently archaeological stratigraphy), cannot be exhibited for technical or doctrinal reasons, an artistic installation can become an efficient tool - a transmitter of the spirit of the place.

\section{Discussing examples}

\section{House of Benjamin Franklin in Philadelphia designed by Robert Venturi and John Rauch (1976)}

Designed by an American designing office Venturi and Rauch (currently known as Robert Venturi, Denise Scott Brown \& Associates), Franklin Court is a museum and a monument of Benjamin Franklin, located in the Historical National Park of Independence in Philadelphia. It is a symbolic reconstruction, a place to commemorate the man generally regarded as a statesman, a politician, a diplomat, a scientist and an inventor, who moved from his native Boston to Philadelphia at the age of 17 , and lived there till the end of his life. It was thanks to his efforts that the University of Philadelphia was established in 1974, and then began its political and social activity aimed at the intellectual development of the community of Pennsylvania. ${ }^{8}[8]$ In this context, in relation to the created work of art the question about the image, projection, presentation of history, identity of the place, and a memorial place seems to be significant. What form of conduct, form of interference in the existing space will be appropriate and legible? Can the method of traditional reconstruction of a historic building, like putting up a traditional statue (which is a figural-allegorical bulk on a pedestal, whose significance is to remain unaltered $)^{9}[9]$ in the urban space, constitute a solution aiding a new and unconventional way of thinking about art, in keeping with the spirit of the times, and allowing for a free sculpting of our imagination? I think that the most important is the memory of everything i.e. remembering the place as a space with all its sensory aspects. Remembering not only the course of events, but also the fragrance of the air, or the colour of the sky in those times, we will be closest to those who are with us no longer. But this kind of remembrance will

\footnotetext{
8 J. A. Daszyńska, Od "Junto” do Uniwersytetu - starania Benjamina Franklina o rozwój intelektualny społeczeństwa w Pensy/wanii (1727-1754), Acta Universitatis Lodziensis. Folia Historica 57/1996, p. 47.

${ }^{9}$ G. Świtek, Gry z architekturq. Nowoczesne powinowactwa i współczesne ingerencje, Toruń 2013, p. 545.
} 
be allowed only in the presence of an oblique artwork which will leave empty space in our minds for individual choices and interpretations, for creation. Only then can we feel the past, the truth about a place which carried in it the burden of history. As Kazimierz Malewicz wrote: Only dumb and helpless artists conceal there are behind honesty. Art needs the truth, not honest. ${ }^{10}[10]$ It is not possible to predict how a viewer might react to such an artwork, yet it certainly depends on the context of the place and on the artist's conduct which should be in keeping with the principles of preservation and conservation treatment, as well as architectonic continuum. We can then talk about an artistic revitalisation of the place, an unconventional though appropriate method of reconstruction. Such a problem of an unconventional reconstruction in historic tissue was faced by the architects Venturi and Rauch. Franklin Court is an example of visual activities oscillating in between architecture, sculpture and installation, art in the public space, an artwork that did not assume the form of a traditional statue or a reconstructed historic object. The architects did not recreate the house of Benjamin Franklin, but made a symbolic negative of the historic form. Above the ground they erected a metal structure imitating the outline of the building rising from the preserved foundations. ${ }^{11}[11]$ The challenge was in designing a structure suitable in the context, yet distinctive, which would illustrate the history of the site in the viewer's imagination.

\section{Il. 1. House of Benjamin Franklin in Philadelphia designed by Robert Venturi and John}

Rauch (1976), source of illustration: httpspl.pinterest.compin524458319097060364.

\section{Basilica di Siponto. SipontoArchaeological Park in Puglia, in the Italian commune of Foggia - artistic installation Edoardo Tresoldi (2016)}

Eduardo Tresoldi is a young, talented, Italian sculptor and set designer, renowned for his realistic sculptures made using the technique of metal mesh. His works are installed in strategic places, entirely integrated with the surroundings. Tresoldi creates openwork, ethereal and at the same time monumental constructions evoking the spirit of the place. Finding his inspiration in the works of old masters of the Italian Renaissance or neoclassicism, he creates ephemeral form, light and transparent, bringing to mind the mist dispersing above the sea. In 2016, he carried out a phenomenal revitalisation of the Romanesque church in Puglia, in the Italian commune of Foggia, where he resurrected the $13^{\text {th }}$-century basilica destroyed hundreds

\footnotetext{
${ }^{10}$ K. Malewicz, Od kubizmu i futuryzmu do suprematyzmu. Nowy realizm w malarstwie (1915), [in:] Między sztukq a komunq. Teksty awangardy rosyjskiej 1910-1932, prep. by A. Turowski, Kraków 1998, p. 154.

${ }^{11}$ G. Świtek, op.cit.
} 
of years ago. Tresoldi made an artistic installation simulating a real model of an early-Christian church in the scale 1:1. ${ }^{12}[12]$ The wire form or the sculpture entitled: Basilica di Siponto, filled an enormous space. Despite its majesty, this spectacular construction appears immaterial and incompletely drawn. The extremely intricate work of the artist was created as a superstructure erected on the relics of the ruins of the early-medieval basilica, where archaeological research had been conducted. The realisation is an example of educational exhibition, documenting a commemorative site. The characteristic arrangement of interpenetrating solids, arches, vaults, walls and columns in the Romanesque style, introduce the viewer into the symbolically restored space of the former church. The realisation is much more than the revitalisation of a site; it is its restitution offering a possibility of time travel. Through his work, the artist adds a new dimension to relations between the past and the present, between the sacred and the profane.

I1. 2. Basilica di Siponto. Siponto Archaeological Park in Puglia, in the Italian commune of Foggia - artistic installation by Edoardo Tresoldi (2016), source of illustration: https://www.edoardotresoldi.com/.

\section{Bohaterów Getta Square designed by Piotr Lewicki and Kazimierz Latak (2015)}

$$
\text { you must not forget! }{ }^{13}[13]
$$

An example of realisation alluding to the Young, German tradition of anti-monuments (from the $2^{\text {nd }}$ half of the 1980s) is the objects realised in 2015 on the Bohaterów Getta Square in the Podgórze district of Krakow. The monument was designed by Piotr Lewicki and Kazimierz Łatak (Lewicki Łatak Designing Office). The monument has the form consisting of several dozens of empty, disproportionate chairs, made from bronze. It was realised within the adaptation of the square to include a commemorative site, as homage paid to the Jews of Krakow. Today's perception of the space of Podgórze focuses on the tragic events from the time of World War II It is the space of Polish-Jewish-German memory. Such a space is generally defined by places which, to quote Cicero: have a power to bring back memories. ${ }^{14}[14]$ A characteristic feature of that monument is avoiding a representation, which is why it fits in with the tradition of anti-monuments. The chair is merely a symbol, a means emphasising the

\footnotetext{
12 https://www.edoardotresoldi.com/; access: 25.06.2018.

13 A. Assmann, Memory of places - authenticity and commemorating, transl. J. Górny, [in:] A. Assmann, Transformations between History and Memory. Anthology, ed. M. Saryusz-Wolska, Warszawa 2013, p. 169.

${ }^{14}$ Cicero, On the Chief Good and Evil, [in:] Cicero, Philosophical writings, vol. 3, transl. W. Kornatowski, Warszawa 1961, p. 379.
} 
emptiness, loss, human tragedy that occurred in this place. The monument consists of negative casts of real chairs. We can see here a departure from the conventional form of sculpture, or traditional approach to a monument. It was the anti-monumentalism driving the authors that determined the de-materialism and ephemerality of the work of art, and situating it on the edge between the visible and the recognisable by the literal disappearance of the matter. The Bohaterów Getta Monument is something that entirely absorbs our attention, a symbol of annihilated existence, a token, a road-sign, a categorical imperative for memory. ${ }^{15}[15]$

Il. 3. Bohaterów Getta Square designed by Piotr Lewicki and Kazimierz Latak (2015), photo: W. Szymański, source of illustration: https://www.riha-journal.org/articles/2015/2015-aprjun/special-issue-contemporary-art-and-memory-part-2/szymanski-podgorze-pl.

\section{Conclusion}

Treating human culture as a factory of permanence ${ }^{16}[16]$, which is connected to the awareness of inevitable death, we elevate human existence above the natural sphere of being, space and time. Our cultural activity is manifested in fighting for survival, removing the moment of death. At the same time, we naturally aspire to attain immortality, which is demonstrated in our wish to leave a trace. Therefore, creative activity of man can be perceived as an effort to instil some sense in life. Art in public space is based on building symbolic systems in which the viewer will be able to move in any way he wishes, discovering, giving and expressing meanings. An artist operating within the public space creates a symbolic dimension of social life. At the same time, he allows the viewer to reach his own understanding and interpretation of symbols.

\section{Bibliografia}

1. The author uses the term aesthetic experience as understood in accordance with the definition by Roman Ingarden; [att.: R. Ingarden, Studia z estetyki, vol. III, Warszawa 1970].

2. Z. Benedyktowicz, D. Markowska, O niektórych problemach identyfikacji kulturowej w procesie porozumiewania się, Etnografia Polska 1988, vol. XXIII, z. 2, ISSN 0071-1861, p. 205-207.

\footnotetext{
${ }^{15}$ W. Szymański, Miejsce pamięci - pomnik - anty-pomnik. Artystyczne strategie upamiętniania na terenie krakowskiego Podgórza, https://www.riha-journal.org/articles/2015/2015-apr-jun/special-issue-contemporaryart-and-memory-part-2/szymanski-podgorze-pl; access (25.06.2018).

${ }^{16}$ Z. Bauman, Mortality, Immortality and Other Life Strategies, Wydawnictwo Naukowe PWN, Warszawa 1998, [att: A. Walczak, O symbolu w kulturze i jego rozumieniu, [in:] Kultura i Wychowanie, No 1 (1) 2011, p. 87.
} 
3. Ł. Guzek, Funkcja dokumentacji w sztuce wspótczesnej, [in:] Sztuka i dokumentacja, no 3/2010, p. 5-13.

4. G. Dziamski, Przełom konceptualny i jego wpływ na praktykę i teorię sztuki. Filozofia i Logika (Poznań: Wydawnictwo Naukowe UAM, 2010), p. 250-51.

5. G. Dziamski, Przełom konceptualny ..., op.cit., p. 252

6. P. Sztabińska, Dokumentacja, ślad i kreacja artystyczna, [in:] Sztuka i Dokumentacja no 10 (2014), p.7582.

7. Ł. Guzek, Biografia w badaniach nad sztuk performance. Proponowane zakresy tematyczne i metody, [in:] Sztuka i Dokumentacja, no 11 (2014,) p. 104-105.

8. J. A. Daszyńska, Od „Junto” do Uniwersytetu - starania Benjamina Franklina o rozwój intelektualny społeczeństwa w Pensy/wanii (1727-1754), Acta Universitatis Lodziensis. Folia Historica 57/1996, p. 47.

9. G. Świtek, Gry z architekturq. Nowoczesne powinowactwa i współczesne ingerencje, Toruń 2013, p. 545.

10. K. Malewicz, Od kubizmu ifuturyzmu do suprematyzmu. Nowy realizm w malarstwie (1915), [in:] Między sztukq a komunq. Teksty awangardy rosyjskiej 1910-1932, prep. by A. Turowski, Kraków 1998, p. 154.

11. G. Świtek, op.cit.

12. https://www.edoardotresoldi.com/; access: 25.06.2018.

13. A. Assmann, Memory of places - authenticity and commemorating, transl. J. Górny, [in:] A. Assmann, Transformations between History and Memory. Anthology, ed. M. Saryusz-Wolska, Warszawa 2013, p. 169.

14. Cicero, On the Chief Good and Evil, [in:] Cicero, Philosophical writings, vol. 3, transl. W. Kornatowski, Warszawa 1961, p. 379.

15. W. Szymański, Miejsce pamięci - pomnik - anty-pomnik. Artystyczne strategie upamiętniania na terenie krakowskiego Podgórza, https://www.riha-journal.org/articles/2015/2015-apr-jun/special-issuecontemporary-art-and-memory-part-2/szymanski-podgorze-pl; access (25.06.2018).

16. Z. Bauman, Mortality, Immortality and Other Life Strategies, Wydawnictwo Naukowe PWN, Warszawa 1998, [att: A. Walczak, O symbolu w kulturze i jego rozumieniu, [in:] Kultura i Wychowanie, No 1 (1) 2011, p. 87. 